\title{
LAPAROSCOPIC INSEMINATION OF SHEEP IN REPUBLIC OF SERBIA
}

\author{
A.Milovanović $^{1}$, N. Maksimović ${ }^{2}$, T. Barna ${ }^{1}$, M. Lazarević ${ }^{3}$, N. Delić ${ }^{2}$ \\ ${ }^{1}$ Scientific Veterinary Institute "Novi Sad", Rumenački put 20, 21000 Novi Sad, Republic of Serbia \\ ${ }^{2}$ Institute for Animal Husbandry, Autoput 16, P. Box 23, 11080 Belgrade-Zemun, Republic of Serbia \\ ${ }^{3}$ Faculty of Veterinary Medicine, Bulevar oslobođenja 18, 11000 Belgrade, Republic of Serbia \\ Corresponding author: aca@niv.ns.ac.rs \\ Original scientific paper
}

Abstract: This paper describes a procedure of laparoscopic insemination (LAI) performed in 42 Ile de France ewes with deep-frozen rams' semen. Frozen semen doses was imported from France, originating from two rams (A and B), and used intermittently in three LAI cycles on different females. The ewes were examined ultrasonographically for pregnancy, two months following insemination and data of lambing were recorded at the end. Total achieved lambing rate was $61.90 \%(26 / 42)$ and total number of lambs was 49 (prolificacy 1.88; 1.16 lambs per sheep included in LAI protocol). Three labs from 2 ewes were stillborn and one dyed at $10^{\text {th }}$ day after lambing. Lambing rates for rams $\mathrm{A}$ and $\mathrm{B}$ were $53.85 \%$ $(14 / 26)$ and $75.00 \%(12 / 16)$, respectively. Introduction of laparoscopic insemination of sheep with imported deep-frozen semen of top quality rams, gaining technical experience and achieving conception rate over $65 \%$ could make this technique acceptable in improving genetic potential of top quality sheep flocks.

Key words: frozen-thawed semen, laparoscopic insemination, sheep

\section{Introduction}

Although artificial insemination (AI) of sheep has been used for several decades, this technique is not as widespread in ovine as it is in other domestic species. Artificial insemination of sheep has been considered impractical for a long time, because of the difficulties in detecting estrus, control of sexual cycle and difficulties in semen freezing. Even if some of these problems are solved, the success of insemination (especially with frozen semen) still remains low because deposition of semen through the cervical opening in sheep is technically very difficult. Unlike to cervix anatomy in cows and goats, cervix in sheep is a firm barrier to the passage of instruments for transcervical intrauterine insemination not only because of the physical size and the narrow diameter of the cervical channel (1-3 mm, even in estrus), but also because of its highly complex fibrous structures, 
with 3 to 7 cervical folds (Halbert et al., 1990) and downed uterine mouth (beak like entrance of portio vaginalis uteri) that often closes cervical orifice.

In 1982 Australian researchers Killeen and Caffery introduced procedure of sheep insemination by laparoscope, which brought a revolution in this field (Evans and Maxwell, 1987; Gourley and Riese, 1990). Laparoscopy through the abdominal wall, with minimal incision, allowed artificial insemination and embryo transfer (ET) directly into uterus of ewes. However, for this procedure, expensive equipment and well-trained team are required. Fertility results among practitioners are still inconsistent because many factors contribute to success of any AI program. In this sense, Anel et al. (2005) analysed 44488 inseminations in the Churra breed (Spanish milk breed), showing a great difference between vaginal-cervical inseminations (refrigerated sperm) and laparoscopic inseminations (thawed sperm) with regard to fertility, as well between farms, years, seasons, age of ewes, lambing-AI interval, ram and technician. Generally, conception rate for LAI was $44.9 \%$ and for vaginal insemination $31.6 \%(\mathrm{P}<0.001)$.

Anyway, laparoscopic artificial insemination (LAI) is now being used in the sheep industry around the world as a standard method to extend the use of superior rams. It offers the farmer opportunity to maximize reproductive potential of sheep. The primary economic benefit to the sheep producer is rapid infusion of valuable genetic traits into the flock (Luther, 2008). Semen trading between countries is only possible with frozen semen and thus using LAI is of paramount importance.

Also, AI is the first choise for disease controll. Moving rams between farms is prohibited in many regions in Norwey in order to control the emergence of scrapie and maedi visna, resulting in increasing interest among farmers for AI activities (Paulenz et al., 2007). Seroprevalence of maedi visna in north Serbia was $21 \%$, with variations between regions from $14-30 \%$ (Savić et al., 2012). Results of the analysis of 116 pedigreed rams in Vojvodina revealed that the current approach to the selection of licensed rams is absolutely no guarantee of reliable fertility or acceptable health status of elite rams (Milovanovic et al., 2011). Spreading of artificial insemination would, in this sense, facilitate the selection service activities and could provide an opportunity for farmers to obtain high quality and health tested breeding rams.

This article is one of the first describing LAI technique performed in the Republic of Serbia.

\section{Materials and Methods}

Forty-two sheep of Ile de France breed were inseminated on three occasions, (20 sheep on May 2012, 5 on June 2012 and 17 on February 2013), at a private sheep farm. Age of sheep ranged from 2 to 8 years. The average weight of sheep was $50 \mathrm{~kg}$ (45-65), with a lower body condition score $(\mathrm{BCS}=2.5 ; 2,0-4,0)$ 
according to Thompson and Meyer (1994), (BCS scale from 1 - 5, where $1=$ emaciated, $5=$ obese condition). In all sheep in the group, at least three months have elapsed since the last lambing. Estrus was synchronized with vaginal progesterone sponges (Chronogest, Intervet-The Netherlands). After 15 days, sponges were removed and sheep were injected $\mathrm{i} / \mathrm{m}$ with $500 \mathrm{IU}$ of PMS (Folligon ${ }^{\circledR}$, Intervet-The Netherlands). The sheep were deprived of food for 24 hours and water for 12 hours before insemination. Insemination was performed 54 - $58 \mathrm{~h}$ after the sponge removal, regardless to the estrus signs. Semen of two elite Ile de France rams (A and B), from the French sheep center, were shipped in the tank of liquid nitrogen. Semen was diluted in milk extender and packed in the classic $0.25 \mathrm{ml}$ mini straws and its quality was not analyzed further. Semen was thawed in automatic semen water bath (Cytoproduct Inc., WI, USA) at $35^{\circ} \mathrm{C}$ for 12 minutes. Twenty six ewes were inseminated with semen from the ram A and sixteen ewes were inseminated with semen from the ram B.

\section{Laparoscopic insemination}

Ewes were fixed in laparoscopic cradle (IMV, L'Aigle, France) in the dorsal position immediately before insemination. After shearing of the wool on the abdominal wall in front of the udder, skin was sprayed with solution of povidone iodine (Hemofarm Vrsac) and subcutaneous injection of $2 \mathrm{ml}$ of procaine (lidocaine-chloride 1\%, Galenika) was applied on the left and right side, $10 \mathrm{~cm}$ cranially from the udder and $2 \mathrm{~cm}$ lateral to the midline. Incision $(1 \mathrm{~cm}$ in length) was performed at the site of application of the local anesthetic with a disposable scalpel no. 11 (Romed, The Netherlands). Sheep were raised and inclined at an angle of $40^{\circ}$ with hydraulic system of laparoscopic cradle, facing down the head. In this way, internal organs were shifted cranially due to the effects of gravity, decreasing the pressure on the caudal region. This position allows the visualization of the uterine horns. Right side of abdominal wall is then pierced with $7 \mathrm{~mm}$ trocar with cannula, directed caudally. The air was inflated using the pump with air filter and laparoscope with a source of cold light (Storz, Germany) was introduced into peritoneal cavity. The $5 \mathrm{~mm}$ trocar with cannula was introduced through the abdominal wall in the same way on the left side, at the site of the second incision. After removing the trocar, specially equipped insemination gun for laparoscopic insemination (IMV, L'Aigle, France) was positioned through the opening of the cannula. Laparoscopic insemination gun consists of loaded semen doses in a plastic sleeve with a fine needle at the top (aspic-a rigid plastic sleeve $25 \mathrm{~cm}$ long with a diameter of $3 \mathrm{~mm}$, with a tapered end with a needle of $0.7 \mathrm{~mm}$ external diameter). Semen with aspic is set in a steel tray (transkap) with a special plunger of semen to allow the controlled extrusion of desired amount of semen from straw. 
After visualization of uterine horns by laparoscope and positioning pistol in the upper third of the horn, the tip of the needle was released from the transkap and decisive thrust to pass into the lumen of the uterus was made. Puncture was performed at $3-5 \mathrm{~cm}$ from the tip of the uterine horn. Half semen dose was ejected into the lumen of the left, and half the dose into the lumen of the right uterine horn. After surgery the wounds on the skin were sprayed with solution of povidone iodine (Hemofarm Vrsac) and left to heal per secundam. Instruments were immersed in container with solution of povidone iodine between two inseminations.

Slow visualization of uterine horns, barriers of fat and omentum between the uterus and laparoscopic lens or inseminating gun significantly slowed down insemination procedure. This was corrected by increasing inclination of laparoscopic cradle compared to originally-fabricated level (IMV laparoscopic cradle, France). Preparation of LAI gun (firm positioning of straws in the aspic and then aspic into the transkap) is very important to prevent extrusion of straws from the LAI gun (instead of semen only). Acquiring skills of the operator and aiding crew, the whole process from animal preparation to the insemination lasted 5 to 8 minutes. The act of insemination (starting from skin incision to the removal of LAI instruments) lasted from 1 to 3 minutes.

In the next 40 days after insemination a ration with moderate supply of concentrate was provided, keeping attention not to disturb animals by unnecessary procedures, rough handling or chasing. Access to the water and hay was ad libidum. The sheep were separated from the rams for a period of 14 days, in order to avoid the possibility of mating with rams on the farm in a cycle that was planned for LAI.

Ewes were scanned for pregnancy by ultrasound (WED 3000, Welld, China) with linear transducer, frequency of $5 \mathrm{MHz}, 60$ days after insemination. The diagnosis of pregnancy was based on the visualization of fetal structures and placentomas.

\section{Results and Discussion}

Total pregnancy rate in three cycles of insemination was $61.90 \%(26 / 42)$. Twenty six inseminated sheep gave birth to 49 lambs (10 singletons, 9 twins and 7 triplets), with 3 stillborns from two ewes and one mortality at $10^{\text {th }}$ day after lambing $(4 / 49,8.17 \%$ total lambs lost). Number of lambs per ewes lambed was 1.88 lambs (49/26), and 1.16 lambs per all sheep included in LAI protocol (49/42). Lambing results corresponded to scanning records regarding pregnancy status of the sheep. 
Conception rate of the ram A (first used in the insemination on twenty six ewes) was $53.85 \%$ (14 out of 26 inseminated sheep), while the ram B scored $75.00 \%$ (12 of 16 inseminated sheep).

Table 1. LAI results (lambing and prolificacy per ewes and conception rates per rams)

\begin{tabular}{|c|c|c|c|c|c|}
\hline \multicolumn{6}{|c|}{ Lambing and fecundity } \\
\hline $\begin{array}{c}\text { No of ewes } \\
\text { insaminated }\end{array}$ & $\begin{array}{c}\text { No of } \\
\text { ewes } \\
\text { lambed }\end{array}$ & $\begin{array}{c}\text { No of } \\
\text { lambs } \\
\text { born }\end{array}$ & $\begin{array}{c}\text { No of } \\
\text { lambs/ewes } \\
\text { lambed } \\
\text { (prolificacy) }\end{array}$ & $\begin{array}{c}\text { No of } \\
\text { lambs/ewes } \\
\text { inseminated }\end{array}$ & mortality No/(*\%) \\
\hline 42 & 26 & 49 & 1.88 & 1.16 & $3(6,12 \%)$ \\
\hline \multicolumn{6}{|c|}{ Conception per rams } \\
\hline \multicolumn{7}{|c|}{$\begin{array}{c}\text { No of ewes } \\
\text { inseminated }\end{array}$} & No of ewes pregnant & Conception rate \% \\
\hline Ram A & \multicolumn{2}{|c|}{26} & 14 & 53.85 \\
\hline Ram B & 16 & 26 & 75.00 \\
\hline total & 42 & 261.90 \\
\hline
\end{tabular}

The literature states that the conception after laparoscopic insemination with frozen semen ranged from 43.9\% (Kusick et al.1999), 48\% (Windsor et al., 1994) to $72 \%$ (Hill et al., 1998). Trained teams can expect success from $60 \%-75 \%$ (Cheminau et al., 1991; Evans and Maxwell, 1987). Pregnancy rates can varie with type of progestagen implant and dosage of PMSG. The pregnancy rate obtained with Medroxy-progesterone acetate (MAP) sponges, was significantly $(\mathrm{P}<0.01)$ lower than with Fluorogestone acetate. A PMSG dose of 200 IU resulted in significantly $(\mathrm{P}<0.05)$ lower pregnancy rates compared with $250 \mathrm{IU}, 300 \mathrm{IU}$ and $\geq$ 375 IU (Hill et al., 1998).

LAI efficiency with frozen semen in sheep can be improved by ram introduction in proestrus. There was a a marked rise in LH concentration in ewes 2 $\mathrm{h}$ after exposing to rams. Pregnancy rate was $73.3 \%$ after ram induced ovulation compared to $53.3 \%$ of control group.

Large study in Spain on 26817 milking sheep inseminated by LAI with thawed semen referred pregnancy rate of $44.89 \%$ and only $31.25 \%$ on 17631 inseminations by cervical technique with chilled semen (Anel et al., 2005).

Generally, the cervical insemination of sheep with frozen semen is not considered practical because the fertility ranges from $25-45 \%$ (Evans and Maxwell, 1987). The exception is Norway's method, where success of $57-69 \%$ has been achieved with frozen semen, after vaginal or cervical semen deposition (Paulenz et al., 2004; Paulenz et al., 2007). In this case, the insemination was carried out only after the detection of natural estrus by teaser rams.

First LAI results with frozen-thawed semen in our trial promising and encourage us to give priority to LAI procedures in sheep breeding. 
Lower fertility of $58.85 \%$ obtained in our study after the use of ram A semen could be addressed to the lack of team experience at the beginning of LAI (LAI was performed for the first time), or, possibly, lower untested semen fertility.

Sheep should be prepared better by the farmers, and the selection of animals should be adequate. Sheep with body condition below 3.0 should not undergo the LAI procedure if expected conception rates are over $70 \%$.

\section{Conclusion}

The introduction of laparoscopic insemination of sheep, import of deep-frozen semen of the top quality rams with good conception rate can make this technique acceptable to improve genetic potential of high-quality sheep. This technique is the "front door" for introducing top rams from any part of the world, and modern producers should have opportunity for far more rapid genetic progress in a short period of time. The method itself is minimally invasive.

An import of frozen semen is significantly easier than the import of live animals, the cost of purchase and transportation are lower, as well as the risk of transmission of infectious diseases. The semen from rams is always of proven health and breeding quality.

\section{Laparoskopsko osemenjavanje ovaca u republici Srbiji}

\section{A. Milovanović, N. Maksimović, T. Barna, M. Lazarević, N. Delić}

\section{Rezime}

U radu je opisan postupak laparoskopskog osemenjavanja (LAO) primenjen kod 42 ovce rase Ile de France duboko zamrznutim semenom. Tokom tri ciklusa osemenjavanja naizmenično je korišćeno seme dva ovna (A i B), uvezeno iz Francuske. Nakon dva meseca od osemenjavanja ovce su pregledane na sjagnjenost ultrasonografskom metodom i analizirani su podaci o jagnjenju. Ostvarena je koncepcija od 61,90\% (26/42) i dobijeno je ukupno 49 jaganjaca (indeks jagnjena 1,88 po ojagnjenoj ovci, odnosno, 1,16 jagnjeta po ovci uključenoj u protokol LAO). Tri jagnjeta od dve ovce bila su mrtvorođena i jedno jagnje je uginulo 10. dana nakon jagnjenja.

Sjagnjenost od semena ovna A iznosila je 58,85\% (14/26) a od ovna B $75,00 \%(12 / 16)$.

Uvođenje laparoskopskog osemenjavanja ovaca, uvoz duboko-zamrznutog semena vrhunskih ovnova, sticanje iskustva i ostvarenje koncepcije od preko $65 \%$ 
može ovu tehniku učiniti prihvatljivom u popravljanju genetskog potencijala kvalitetnih stada ovaca.

\section{References}

ANEL L., KAABI M., ABROUG B., ALVAREZ M., ANEL E., BOIXO J.C., DE LA FUENTE L.C., DE PAZ P. (2005): Factors influencing the success of vaginal and laparoscopic artificial insemination in churra ewes: a field assay. Theriogenology, 63, 1235-47.

CHEMINEAU P., CAGNIE Y., GUERIN Y., ORGEUR P., VALLET J.C. (1991): Training manual on artificial insemination in sheep and goats, FAO animal production and health paper 83, Food and Agriculture organization of the United Nations, Rome.

EVANS G., MAXWELL W.M.C. (1987): Salamon's Artificial Insemination of Sheep and Goats, Butterwords (Ed), Sydney, p.200.

HALBERT G.W., DOBSON H., WALTON J.S., BUCKRELL B.C. (1990): The structure of the cervical canal of the ewe, Theriogenology, 33, 977-92.

HILL J.R., THOMPSON J.A., PERKINS N.R. (1998): Factors affecting pregnancy rates following laparoscopic insemination of 28447 Merino ewes under commercial conditions: a survey. Theriogenology, 49, 697-709.

KILLEEN I.D., CAFFERY G.J. (1982): Uterine insemination of ewe with the aid of a laparoscope. Australian Veterinary Journal, 35, 256.

KUSICK B.C., THOMAS D.L., GOTTFREDSON R.G., ZELINSKY R.D., BERGER Y.M. (1999): A Comparison of Transcervical and Laparoscopic Intrauterine Artificial Insemination Techniques on Reproductive Performance of Ewes.http://www.ansci.wisc.edu/Extension-

New\%20copy/sheep/Publications_and_Proceedings/Pdf/Reproduction/Transcervic al\%20and\%20laparoscopic\%20artificial\%20insemination\%20techniques.pdf.

LUCIDI P., BARBONI B., MATTIOLI M. ( 2001): Ram-induced ovulation to improve artificial insemination efficiency with frozen semen in sheep. Theriogenology, 55, 9, 1797-1805.

LUTHER J. S. (2008) Application of Laparoscopic Artificial Insemination Techniques to the North Dakota Sheep Industry, Sheep Research Report, NDSU Department of Animal Sciences, 24-6.

MAXWELL W.M.C., WATSON P.F. (1996): Recent progress in the preservation of ram semen. Animal Reproduction Science, 42, 1-4, 55-65.

MILOVANOVIĆ A., BARNA T., BUGARSKI D., SAVIĆ S., GRGIĆ Ž., STOJANOV I. (2011): Results of ram fertility control in Northern Serbia. 19th International Congress of Mediterannean Federation of Health and Production of Ruminants, May 25-28, Belgrade. Congress Proceedings, 433-41. 
PAULENZ H., ADNOY T., SODERQUIST L. (2007): Comparison of fertility results after vaginal insemination using different thawing procedures and packages for frozen ram semen. Acta Veterinaria Scandinavica, 49, 26.

PAULENZ H., SODERQUIST L., ADNOY T., NORDSTOGA A.B., GULBRANDSEN B., ANDERSEN BERG K. (2004): Fertility results after different thawing procedures for ram semen frozen in minitubes and mini straws. Theriogenology, 61, 1719-27.

SAVIĆ S., VIDIĆ B., BUGARSKI D., GRGIĆ Ž.: Findings of specific antibodies against Maedi-visna virus in sheep population in the Region of Vojvodina. The Forth Joint UNS-PSU International Conference on Bioscience [with topic] Biotechnology and Biodiversity - Step in the Future, Novi Sad, June 18-20, 2012, editors Mirjana Milošević ... et al., Book of Proceedings, 109-114, Novi Sad, Institute of Field and Vegetable Crops, 2012.

THOMPSON J., MEYER H. (1994): Body condition scoring of sheep. EC 1433, Oregon State University Extension Service.

WINDSOR D.P., SZELL A.Z., BUSHBECK C., EDWARD A.Y., MILTON J.T.B., BUCKRELL B.C. (1994): Transcervical artificial insemination of Australian Merino ewes with frozen-thawed semen. Theriogenology, 42, 147-57. 